\title{
CORPORATE LAW AND SOCIAL NORMS
}

\author{
Melvin A. Eisenberg*
}

Corporate law serves both to facilitate and to regulate the conduct of the corporate enterprise. Insofar as corporate law is regulatory, it provides incentives and disincentives to the major actors in the corporate enterprise-directors, officers, and significant shareholders-through the threat of liability. In significant part, however, these actors are motivated not by the desire to avoid liability, but by the prospect of financial gain, on the one hand, and by social norms, on the other. Much work has been done on the way in which these actors are motivated by the threat of liability and the prospect of financial gain, but relatively little work has been done on the operation of social norms. The purpose of this Article is to illuminate both corporate law specifically, and the interrelation of law and social norms generally, by studying the ways in which that interrelation operates in the field of corporate law. The Article begins by describing three kinds of social norms-behavioral patterns, practices, and obligational norms - and considering the origins and effects of social norms. It then examines the critical role of social norms in several central areas of corporate law: fiduciary duties (specifically, care and loyalty), corporate governance (specifically, board composition and the role of institutional investors), and takeovers.

Bill Cary was the leading figure in corporate law from the early 1960s, when he assumed the chairmanship of the Securities and Exchange Commission, until his death. No one was his equal in seeing the large picture. With his passing, a figure of remarkably clear vision and great moral and intellectual stature left the scene. This Article is written with Bill's teachings very much in mind.

\section{INTRODUCTION}

Corporate law serves both to facilitate and to regulate the conduct of the corporate enterprise. Insofar as corporate law is regulatory, it provides incentives and disincentives to the major actors in the corporate enterprise-directors, officers, and significant shareholders-through the threat of liability. In significant part, however, these actors are motivated not by the desire to avoid liability, but by the prospect of financial gain, on the one hand, and by social norms, on the other. Much work

* Koret Professor of Law, University of California at Berkeley; Justin W. D'Atri Visiting Professor of Law, Business, and Society, Columbia Law School. A.B. Columbia College 1956; LL.B. Harvard 1959.

I thank Bob Cooter, Jeff Gordon, Kent Greenawalt, Don Langevoort, Eric Posner, Mike Smith, and Omri Yadlin for their valuable comments, and Paula Blizzard, Marlena Byrne, and Tania Mortensen for important research assistance.

An earlier version of this Article was presented as the Inaugural Lecture for the Justin W. D'Atri Visiting Professorship in Law, Business, and Society. 
has been done on the way in which these actors are motivated by the threat of liability and the prospect of financial gain, but relatively little work has been done on the operation of social norms.

The neglect of the operation of social norms in the field of corporate law parallels the neglect of the operation of social norms in the law generally. ${ }^{1}$ In recent years, a small but important group of scholars has begun to remedy this neglect. ${ }^{2}$ By and large, however, the work has not concerned the interrelation of law and social norms in specific fields of law. Instead, most of the new work has either concerned the operation of social norms in general, using illustrations from various fields, or has concerned occupational communities whose members choose to be governed by their own social norms rather than law in their dealings with each other. ${ }^{3}$ Furthermore, much of this work has concerned only those social norms that impose obligations, and little of the work has concerned the role of belief-systems in the origin and adoption of social norms.

In this Article, I examine the interrelation of social norms and corporate law. The purpose of this examination is to illuminate both corporation law specifically, and the interrelation of social norms and law generally, by studying ways in which that interrelation operates in a specific field. I will focus on three kinds of social norms, which I call behavioral patterns, practices, and obligational norms. In the course of this Article, I will show that even social norms that do not impose obligations play

1. See Eric A. Posner, Efficient Norms, in 2 New Palgrave Encyclopedia of Law and Economics 19, 20 (1998).

2. See, e.g., Robert C. Ellickson, Order Without Law: How Neighbors Settle Disputes (1991); Lisa Bernstein, Merchant Law in a Merchant Court: Rethinking the Code's Search for Immanent Busmess Norms, 144 U. Pa. L. Rev. 1765 (1996); Lisa Bernstein, Opting Out of the Legal System: Extralegal Contractual Relations in the Diamond Industry, 21 J. Legal Stud. 115 (1992) [hereinafter Bernstein, Opting Out]; David Charny, Illusions of Spontaneous Order: Norms in Contractual Relationships, 144 U. Pa. L. Rev. 1841 (1996); Robert D. Cooter, Decentralized Law For a Complex Economy: The Structural Approach to Adjudicating the New Law Merchant, 144 U. Pa. L. Rev. 1643 (1996) [hereinafter Cooter, Decentralized Law]; Robert D. Cooter, Expressive Law and Economics, 27 J. Legal Stud. 585 (1998) [heremafter Cooter, Expressive Law and Economics]; Robert Cooter, Normative Failure Theory of Law, 82 Cornell L. Rev. 947 (1997); Jody S. Kraus, Legal Design and the Evolution of Commercial Norms, 26 J. Legal Stud. 377 (1997); Lawrence Lessig, The Regulation of Social Meaning, 62 U. Cbi. L. Rev. 943 (I995); Richard H. McAdams, The Origin, Development, and Regulation of Norms, 96 Mich. L. Rev. 338, 341 (I997); Richard H. Pildes, The Destruction of Social Capital Through Law, I44 U. Pa. L. Rev. 2055 (1996); Eric A. Posner, Law, Economics, and Inefficient Norms, 144 U. Pa. L. Rev. I697 (1996) [hereinafter Posner, Law, Economics, and Inefficient Norms]; Eric A. Posner, Symbols, Signals, and Social Norms in Politics and the Law, 27 J. Legal Stud. 765 (1998) [hereinafter Posner, Symbols, Signal, and Social Norms]; Eric A. Posner, The Regulation of Groups: The Influence of Legal and Nonlegal Sanctions on Collective Action, 63 U. Chi. L. Rev. 133 (1996) [heremafter Posner, Regnlation of Groups]; Cass R. Sunstein, On the Expressive Function of Law, 144 U. Pa. L. Rev. 2021 (1996) [hereinafter Sunstein, Expressive Function of Law]; Cass R. Sunstein, Social Norms and Social Roles, 96 Colum. L. Rev. 903 (1996) [hereinafter Sunstein, Social Norms].

3. See, e.g., Bernstein, Opting Out, supra note 2. 
important roles in the law, and that belief-systems that result from new information and reasoned persuasion play a fundamental role in the origin and adoption of social norms.

The organization of this Article is as follows: In Part I, I describe and define the kinds of social norms that are relevant to law. In Part II, I consider in a preliminary way the origins and effects of social norms. In Part III, I examine the role of social norms in three central areas of corporate law: fiduciary duties, corporate governance, and takeovers. In the course of that examination, I apply and elaborate the analysis in Parts I and II concerning the kinds, origins, and effects of social norms, and consider some of the types of interrelations between social norms and law.

\section{Descriptions and Definitions}

An analysis of the operation of social norms in the law presents severe problems of terminology. To begin with, as a matter of ordinary language the term norm encompasses both rules and regularities. Because rules and regularities are very different kinds of phenomena, a single canonical definition of the term norm is not within reach. Furthermore, rules and regularities are each comprised of various types of norms, and the typology that is employed in a given inquiry will depend in part on the purpose of the inquiry. I therefore begin by describing the major types of norms that are salient to law, and setting out the definitions that I will employ. These descriptions and definitions, in turn, will set the stage for an inquiry into the manner in which different types of norms operate in areas that are within the scope of law.

\section{A. Social Norms, Legal Rules, and Organizational Rules}

To begin with, I use the term social norm to mean all rules and regularities concerning human conduct, other than legal rules and organizational rules. By legal rules, I mean the principles and rules of a legal system. By organizational rutes, I mean formal rules adopted by private organizations. Such rules often have the effect of legal rules, because they are directly or indirectly backed by legal sanctions. ${ }^{4}$ Even when organizational rules are not backed by legal sanctions they are often backed by formal sanctions, because many private organizations have monopoly power over important parts of the lives of persons who are members or want to become members. Consider, for example, the rules of professional and amateur sports organizations, HMOs, and the Boy Scouts and Girl Scouts.

4. For example, a broker-dealer who violates the rules of the National Association of Securities Dealers may be expelled from that organization, and under the Securities Act a broker-dealer who is not a member of the NASD cannot effect any transaction in a security other than an exempted security or commercial paper. See Louis Loss \& Joel Seligman, Fundamentals of Securities Regulation 629-48 (3d ed. 1995). 
I exclude legal rules from the definition of social norm that 1 use in this Article because the purpose of this Article is to investigate the role of nonlegal rules and regularities. I exclude organizational rules because such rules tend to operate in a much different way than other nonlegal norms; in fact, they tend to operate in many ways like legal rules. Of course, organizational rules can be and often are considered to be social norms. For that matter, legal rules can be and often are considered to be social norms. I exclude those categories from the definition of social norm that 1 use in this Article not because ordinary language requires these exclusions, but for clarity in analysis and convenience in exposition.

\section{B. Three Categories of Social Norms}

Social norms can be divided into three categories according to the degree of self-consciousness and obligation that they involve.

The first category consists of behavioral patterns that neither entail a sense of obligation nor are self-consciously adhered to or engaged in. One type of behavioral pattern consists of functional responses to the facts of the natural world, like putting on warm clothes when it's cold. Another consists of statistical regularities, like the fact that automobile accidents peak during holidays. Still another consists of habits, like drinking coffee at breakfast.

The second category of social norms consists of rules and regularities that are self-consciously adhered to or engaged in, but do not entail a sense of obligation. For example, it is a practice in some law schools to begin "one-hour" classes on the hour and finish at ten minutes of, and in others to begin at ten minutes after the hour and finish on the hour. These practices are self-consciously adhered to and engaged in, and indeed have the look and feel of rules, but they do not involve a sense of obligation. A law school would normally not be criticized for changing from one practice to the other, or to a third practice entirely. A faculty member could normally depart from the practice-make an exception to the rule-without criticism, as long as she could comfortably fit the schedule of her class into the schedules of other classes, and adhered to the related norm that a one-hour law school class lasts 50 minutes.

Another type of norm in this category consists of usages that attach meanings to words, symbols, or stylized conduct. Here is an example from the Restatement Second of Contracts.

$A$ contracts to sell $B 1,000$ feet of San Domingo mahogany. By usage of dealers in mahogany, known to $A$ and $B$, good figured mahogany of a certain density is known as San Domingo mahogany, though it does not come from San Domingo. Unless otherwise agreed, the usage is part of the contract. ${ }^{5}$

5. Restatement (Second) of Contracts $\S 222 \mathrm{cmt}$. b, illus. 2 (1996). 
Another example is the posture and hand signal used to hitchhike: As a matter of usage, standing in a certain posture by the side of a road and holding up your hand in a certain way means that you want a lift.

I will call norms in this second category practices, and I will call behavioral patterns and practices, taken together, nonobligational norms.

The third category of social norms consists of rules or practices that actors not only self-consciously adhere to or engage in, but feel obliged in some sense to adhere to or engage in, although (by hypothesis) the rule or practice is neither a legal nor an organizational rule. I will call such norms obligational norms. An operational test of whether a social norm is obligational is whether a departure from the norm is likely to involve either self-criticism or criticism by others.

Moral norms are one extremely important type of obligational norm. Much human conduct can only be convincingly explained on the basis of moral norms. Even conduct that could be explained on instrumental grounds often has a moral dimension whose explanatory power cannot be safely ignored. ${ }^{6}$ But a social norm may be obligational without being moral. For example, if it is a practice to wear formal dress to Metropolitan Opera premieres, then regular Metropolitan Opera opening nights will probably believe there is an obligation, although not a moral obligation, to follow along. Correspondingly, those who attend a premiere in informal dress will be criticized. Similarly, the social norms concerning what kinds of foods should be eaten with utensils, rather than with one's hands, are not moral norms, but they are obligational norms.

\section{The Effects AND Origins of Social Norms}

I turn now to a preliminary consideration of the origins of social norms and the effects of social norms on human conduct. The effects of social norms depend on two basic variables: (1) whether the norm is obligational, and (2) if it is obligational, whether it has been internalized by the relevant actor. Social norms may originate in a variety of ways. In this Article, I will focus on one way in which social norms originate that is particularly relevant to corporate law: the formation or alteration of belief-systems based on new information, reasoned persuasion, or both.

\section{A. Obligational Norms}

Legal rules provide a reason for acting in a certain way. So do obligational norms. A legal rule may provide a reason for acting in a certain way because the actor has internalized the rule itself or the moral norm of obedience to law, because the actor fears legal sanctions or desires a legal benefit, or because the actor fears external nonlegal sanctions, like reputational sanctions, or desires nonlegal benefits, like reputational gains. Similarly, an obligational norm may provide a reason for acting in

6. See Robert Axelrod, The Complexity of Cooperation 40 (1997). 
a certain way either because the actor has internalized the norm or because the actor fears external sanctions or desires external benefits.

1. Internalized Obligational Norms. - The economist Kaushik Basu usefully describes the operation of internalized obligational norms as follows:

[Certain norms stop] us from doing certain things or choosing certain options, irrespective of how much utility that thing or option gives us. Thus most individuals would not consider picking another person's wallet in a crowded bus. This they would do not by speculating about the amount the wallet is likely to contain, the chances of getting caught, the severity of the law and so on, but because they consider stealing wallets as something that is simply not done.

In traditional economics the 'feasible set' of alternatives facing an individual (from which the person makes his or her choice) is defined in terms of technological or budgetary feasibility. Thus a consumer's feasible set is the collection of all the combinations of goods and services that the consumer can purchase given his or her income. From the above discussion it should be evident that [certain norms] further limi[t] the feasible set, because now certain alternatives may be infeasible to an individual not just because they are technologically infeasible (like walking on water) or budgetarily infeasible (like buying a Jaguar car) but because they are ruled out by the person's norms. ${ }^{7}$

7. Kaushik Basu, Social Norms and the Law, 3 New Palgrave Encyclopedia of Law and Economics 476, 477 (1998). Basu calls the norms he describes in this passage "rationalitylimiting norms" on the ground that "a person endowed with [such] norms may forego options which could have enhanced his utility" - by which Basu seems to mean wealth"and thus such a person would be considered irrational in terms of mainstream economics." Id. at 477. In contrast, he says, some norms always enhance an actor's selfinterest:

[C]onsider the norm, in many countries, of driving on the right. It is true that this norm is additionally fortified by the law; but it is arguable that even if this were just a norm or a convention and not the law, people would still drive on the right. This explains why the police have to be vigilant in enforcing the stop-sign rule or the speeding rule but not the drive-on-the-right rule. The first two are laws which are not in people's selfinterest (they may of course be in their group interest). But the third is a norm which, once it is in place, happens to be entirely compatible with self-interested behaviour. In the absence of such a norm, there are at least two possible equilibria-everyone drives on the left and everyone drives on the right. The norm is very different from the two discussed above because it simiply helps people select an equihibrium. . . I I call such a norm an 'equilibrium-selection norm.' This is the norm the study of which is currently in vogue in economics and has generated a lot of hiterature, to the extent that economists tend to forget about the other kinds of norms-conveniently so, since the equilibrium-selection norm is the one which is most compatible with conventional economics.

Id. 
Basu doesn't address here just why some things are simply not done. It is tempting to answer that question solely in cost-benefit terms, even insofar as the question applies to internalized norms. In the case of moral norms, the internal cost is the pain of guilt-what Robert Cooter refers to as the "guilt penalty." The internal benefit is the satisfaction an actor obtains from doing the right thing-the pleasure of rectitude.

However, an analysis in cost-benefit terms, although important, is insufficient. Moral norms, in particular, often operate by becoming part of an actor's moral character, so that some things are "simply not done"-or simply done-as a result of the actor's moral sympathies and commitments. Martha Nussbaum has captured this point especially well:

[Under a cost-benefit analysis, a]ltruism tends to be reduced to a type of egoism, in which people get reputational or psychic goods for themselves. For some time it has been influentially argued within economics that this approach is inadequate, even for predictive purposes: we need to recognize sympathy and commitment as independent sources of motivation. This is hardly a surprising claim, because it is one that has been argued throughout the history of Western philosophy-starting ... with Aristotle, who argued that people who die for their friends or family cannot plausibly be said to do so for satisfaction, because they are risking or forfeiting, in the process, all prospect of future satisfaction. A theory that focuses on satisfaction will therefore make bad predictions about what they will do. Recently these ideas have been receiving striking empirical confirmation: it has been powerfully argued that economic theories could not have predicted that anyone would risk life, family, comfort, and reputation to rescue Jews during the Holocaust. And yet a significant number of people did.9

More generally, as Basu points out, for many or most actors in many or most situations internalized moral norms operate without a cost-benefit calculation, but instead because for those actors certain things (like picking pockets) are simply not done, while other things (like assisting the unsighted across the street) simply are done.

Obligational norms that are not moral norms may also be internalized, and the effects of such norms may be comparable to those of internalized moral norms. A major effect of internalized norms that are obligational but not moral is the way in which they shape an actor's social character. For regular Metropolitan Opera goers, not dressing formally for opening night may be no more of an option than picking pockets.

This does not mean that cost-benefit analyses fail to figure in the effect of internalized norms. They often do. In deciding whether to adhere to an internalized moral norm, an actor may weigh the pain of guilt, the pleasure of rectitude, and the external costs and benefits of adher-

8. Cooter, Decentralized Law, supra note 2, at 1662.

9. Martha C. Nussbaum, Flawed Foundations: The Philosophical Critique of (a Particular Type of) Economics, 64 U. Chi. L. Rev. 1197, 1211 (1997). 
ence and nonadherence. In deciding whether to adhere to an internalized nonmoral norm, an actor may weigh the pain of shame, the pleasure of conformity, and the external costs and benefits of adherence and nonadherence. Thus character may explain adherence to internalized norms by some actors, while the weighing of internal and external costs and benefits may explain adherence by others. Or, internal and external costs and benefits may figure for some actors some of the time. Having said that, however, it seems likely that most actors who have internalized an obligational norm will usually apply the norm reflexively, as a natural expression of their moral and social character, rather than calculatingly, on the basis of a cost-benefit analysis. Even norms that an actor at first adheres to through a self-conscious commitment to good action will often become habitual second nature through repetition.

2. Noninternalized Obligational Norms. - In contrast to internalized obligational norms, noninternalized obligational norms will be adhered to, if at all, only for instrumental reasons. Thus the effect of such norms in any given case will depend on a comparison of the immediate external gains of nonadherence with the long-term external benefits of adherence and costs of nonadherence. The long-term costs of nonadherence involve loss of reputation, including diminished esteem, public shame (as opposed to feeling ashamed), and disdain. The long-term benefits of adherence involve enhanced reputation, including increased esteem, public recognition, and social acceptance. As shown by Eric Posner, adherence and nonadherence to obligational norms have signaling effects. Adherence to norms signals that one is a cooperator. Nonadherence signals that one is not. An actor who develops a reputation as a cooperator may derive substantial benefits from the cooperation of others. An actor who develops a reputation as a noncooperator may not. ${ }^{10}$

Nevertheless, most obligational norms will originate and stabilize only if they are internalized by a significant portion of the relevant social group. If the sole reason for adhering to an obligational norm is the fear of reputational sanctions for noncompliance, and few or no members of

10. See generally Posner, supra note 1; Posner, Law, Economics, and Inefficient Norms, supra note 2; Posner, Symbols, Signals, and Social Norms, supra note 2; Posner, Regulation of Groups, supra note 2.

Obhigational norms may also be effective because an actor has internalized a metanorm of adherence to the norms of a defined group with which he feels at one. The actor may then adhere to a specific group norm even though he has not internalized that norm and is not motivated by the external benefits or costs that may result from adherence or nonadherence to the norm. This phenomenon is most commonly found where the actor is a nember of a special group that is working toward a shared end, or that shares a special ethos, that the actor believes to be important. In certain respects, unembership in such groups simply sharpens some of the characteristic incentives to adhere to norms-in this case, the norms of the special group. For example, the sanction of disapproval may be especially salient and effective in such a group. However, there is also a special mternal benefit in adhering to the norms of such a group just because they are the norms of the group-the pleasures of belonging, of acting $\mathrm{m}$ a special and good endeavor, and of surrendering narrow individuality to a larger cause. 
the social group internalize the norm-that is, believe that the norm should be adhered to-the norm will probably collapse. ${ }^{11}$ This does not mean that internalization by a significant portion of the social group is sufficient to stabilize an obligational norm. There will usually be some actors who will adhere to an obligational norm only because of fear of reputational sanctions, and the norm might also collapse if there was no reason for such fear. Without a significant degree of internalization, however, reputational effects will usually be insufficient.

\section{B. Nonobligational Norms}

There is a tendency in the legal and economics literature concerning social norms to focus on obligational norms. ${ }^{12}$ It's easy to understand this tendency. In their work on legal rules, legal and economics scholars characteristically emphasize incentives and disincentives, and obligational norms, like legal rules, provide incentives and disincentives. However, obligational norms are not the only kind of social norms that can affect human conduct. Nonobligational norms can have this effect as well.

In a memorable phrase, E.M. Jellinek referred to "the normative power of the actual."13 Jellinek here used "normative" in its obligational sense. What he meant is that practices often take on a certain "oughtness." Partly this phenomenon results from a respect for tradition. That respect need not be irrational. Traditional practices may be ways that have worked, that have stood the test of time, even if we are not entirely sure why any given traditional practice works. ${ }^{14}$ There are other reasons for this phenomenon. Many practices give rise to expectations that they will continue to be followed. If these expectations seem justified to those who hold them, then a failure to follow the practice will be treated as a defeat of justified expectations. If a practice has been relied upon, then a failure to follow the practice will be treated as a defeat of justified reliance. Thus is easily becomes ought, and what begins as a practice may easily end as an obligation. ${ }^{15}$

Then too, many social norms have both nonobligational and obligational faces. For example, social scientists may treat the average age at marriage in a given group as a statistical regularity, while members of the group may feel obliged to marry before reaching that age. The posture and hand signal used to hitchhike is a practice, but it may have an obliga-

11. See H.L.A. Hart, The Concept of Law 56 (2d ed. 1994). The most significant exception is the kind of norm that Basu calls an equilibrium-selection norm, like keeping to the right. Once such a norm is in place, adhering to the norm is compatible with selfinterested behavior even without regard to reputational effects. See Basu, supra note 7.

12. See, e.g., Sunstem, Social Norms, supra note 2, 914-21. An important exception is Kraus, supra note 2.

13. Morris R. Cohen, The Basis of Contract, 46 Harv. L. Rev. 553, 582 (1933).

14. See Robert C. Clark, Contracts, Elites, and Traditions in the Making of Corporate Law, 89 Colum. L. Rev. 1703, 1713, 1726-30 (1989).

15. See Robert Axelrod, An Evolutionary Approach to Norms, 80 Am. Pol. Sci. Rev. 1095, 1107 (1986). 
tional effect if would-be hitchhikers find that if they try to hitch in other ways they won't get rides, either because they are misunderstood or because drivers do not want to give rides to unconventional people.

Finally, a focus on obligational norms overlooks that nonobligational norms may have an important effect on conduct by permitting certain behavior. For example, the norm of racial discrimination in the Jim Crow South might be conceived of as either an obligational norm, to the extent that it obliged even those whites who did not want to discriminate to do so, or as a nonobligational norm that insulated those who engaged in discrimination from both outside criticism and self-criticism. Similarly, if smoking is a prevailing practice, it will be socially permissible. If smoking is no longer a prevailing practice, it may no longer be socially permissible.

\section{Belief-Systems and Social Norms}

Most legal and economic accounts of social norms are directed toward the dynamics that govern the adoption of social norms, and focus on external reasons for adhering to social norms, rather than on internal beliefs. Legal and economics scholars have done very little work on why particular social norms (other than rudimentary coordinating or cooperative norms, which are usually in the self-interest of actors) originate and why norms are often internalized.

A major exception is the work of Robert Cooter, who focuses on three processes by which actors internalize social norms: a Freudian process, in which the repressed memory of parental sanctions for childhood transgressions becomes transmuted into an adult superego; a Piagetian process, in which children perfect their ability to internalize norms as they acquire a capacity for general reasoning; and a Weberian process, in which actors internalize the norms associated with occupational roles. ${ }^{16}$ Cooter's emphasis on the processes by which norms are internalized is relatively unusual in the legal and economic literature on norms, and extremely important. However, each of these processes assumes the prior existence of the norms that are internalized through the processes, rather than explaining how and why particular social norms originate, or why adults internalize new social norms other than occupational role norms.

There is no simple, or at least no single, answer to these questions. Undoubtedly, some social norms, like the prohibitions on murder, theft, and incest, originate because they are necessary for societies to become viable. Others originate because they prove to be efficient and are therefore imitated.

Still other social norms originate or are adopted because actors form a new belief-system-that is, alter their views about the world or their values-on the basis of new information, reasoned persuasion by other

16. See Cooter, Decentralized Law, supra note 2, at 1661-64. 
actors, or both. ${ }^{17}$ The process by which norms originate and are adopted as a result of changes in actors' belief-systems is extremely important generally ${ }^{18}$ and is of special importance in explaining the origin and adoption of many norms that are significant in corporate law. Both for that reason, and because this process has been little studied by scholars who have analyzed the role of social norms in the law, ${ }^{19}$ in this Article 1 will place heavy emphasis on the role of belief-systems in the origin and adoption of social norms. ${ }^{20}$

\section{Critical Mass, Tipping-Points, and Equilibria}

The behavior of actors often depends on their expectations of what other actors will do. In his book Micromotives and Macrobehavior, ${ }^{21}$ Thomas Schelling gives a number of examples. A faculty seminar is begnn. Whether it continues or dies out depends on whether each participant expects that enough other participants will continue to come. Pedestrians gather at a busy intersection, anxious to cross against the light. Whether they do so depends on whether each believes that enough additional pedestrians will cross so that a group sufficiently large to stop traffic will be formed. "The generic name for behaviors of this sort," Schelling notes, is "critical mass." ${ }^{22}$ He continues, "[w] hat all of the criti-

17. Value-systems can be disaggregated from belief-systems. I treat values and other kinds of views about the world together here because it is often difficult to say whether a change in behef-systems is better characterized as a change in values or as a change in views about the implications or applications of values, and the difference is by and large not significant for purposes of this Article.

18. See, e.g., Isaiah Berlin, Four Essays on Liberty 119 (1969):

Over a hundred years ago, the German poet Heine warned the French not to underestimate the power of ideas: philosophical concepts nurtured in the stillness of a professor's study could destroy a civilization. He spoke of Kant's Critique of Pure Reason as the sword with which European deism had been decapitated, and described the works of Rousseau as the blood-stained weapon which, in the hands of Robespierre, had destroyed the old regime; and prophesied that the romantic faith of Fichte and Schelling would one day be turned, with terrible effect, by their fanatical German followers, against the hberal culture of the West. The facts have not wholly belied this prediction.

(froin the essay, Two Concepts of Liberty); see also A.C. Grayling, Family Feuds, N.Y. Times, Sept. 27, 1998, \& 7, at 20 (Book Review) (reviewing Randall Collins, The Sociology of Philosophies: A Global Theory of Intellectual Change (1998)).

19. An exception, again, is Cooter, whose analysis includes a passage that points out that a sinoker may be persuaded to quit sınoking. See Cooter, Decentralized Law, supra note 2 , at 1661 .

20. The discussion in this Article concerning the reasons for the origins and adoption of social norms is highly selective, because many or even most such reasons are not sahent in corporate law. The discipline that perhaps lias the most to say about the origin of norms is sociology. See, e.g., David Garland, Punishment and Modern Society 213-47 (1990).

21. Thomas C. Schelling, Microinotives and Macrobehavior 91-102 (1978).

22. Id. at 94 . 
cal mass models involve is some activity that is self-sustaining once the measure of that activity passes a certain minimum level."23

A special case of the critical-mass phenomenon is known as tipping. ${ }^{24}$ Tipping occurs when the success of a social activity depends on the formation of a critical mass, and enough actors sign on or sign off that the activity succeeds or fails. If enough actors sign on, the activity is tipped in. If enough actors sign off, the activity is tipped out. A consequence of critical-mass and tipping phenomena is that the behavior of a relatively small number of actors can cause an activity to succeed or fail, because a tipping-point may be crossed as a result of the addition or subtraction of a small number of actors.

What is true of social activities in general is often true of social norms in particular. Social norms may shift when, and because, enough actors change their behavior that a tipping-point is crossed. This may occur for various reasons. For example, a tipping-point may be crossed because enough actors change their belief-systems about the desirability of adhering to a norm. Or, it may be crossed because actors who adhere to a norm increase their readiness to sanction actors who do not, and enough nonadhering actors change their behavior in order to avoid these new sanctions. Because a relatively small number of crossover actors may cause a norm to tip in or out, social norms may shift relatively suddenly. ${ }^{25}$

A phenomenon that resembles tipping-points occurs where a social norm is or can be radically changed by the defection of a very small number of actors-perhaps even one or two. This phenomenon may occur because the norm reflects an equilibrium that depends on the fear of the consequences of departing from the norm, and a successful defection allays those fears. Or, it may occur because a successful defection shows that departure from the norm opens up valuable opportunities. More generally, it is a familiar phenomenon that actors may be willing to change their course of conduct if, but only if, others act first.

\section{The Role of Social Norms in Corporate Law}

I now turn to the role of social norms in corporate law. I use the term "corporate" law here in a broad but standard sense to mean those areas of conduct that are within the scope of corporate law, and, more generally, those areas of conduct that are of ongoing concern to the corporate bar and to students of corporate law. Accordingly, I include areas that are regulated only loosely or not at all by legal rules, such as the structure of the board of directors and the role of institutional investors in corporate governance.

23. Id. at 95 .

24. See id. at 101-02.

25. See Robert AxeIrod, The Complexity of Consideration 42 (1997) ("In tipping processes] individuals are willing to act if enough others act first. Under certain circumstances, a slight change in the willingness of a few people to act first can get the ball rolling .... [C] dlective behavior sometimes ... tips suddenly."). 
Some corporate law doctrines explicitly incorporate social norms. For example, the ALI's Principles of Corporate Governance provides that a corporation "may properly take into account ethical considerations that are generally recognized as relevant to the conduct of business," even if corporate profit and shareholder gain are not thereby enhanced. ${ }^{26}$ In United States v. Bestfoods, ${ }^{27}$ the Supreme Court held that in determining whether an action by a dual officer of a parent and a subsidiary was taken on behalf of the parent or on behalf of the subsidiary, "the presumption that an act is taken on behalf of the corporation for whom the officer claims to act is strongest when the act is perfectly consistent with the norms of corporate behavior, but wanes as the distance from those norms" increases. ${ }^{28}$ Similarly, the Court held that in determining whether conduct by a parent's officer involves parental oversight or direct parental control, "the crucial question is whether ... actions ... by agent of the parent alone are eccentric under accepted norms of oversight of a subsidiary's facility."29 My focus here, however, is on social norms that are not explicitly incorporated into legal rules. I consider three central areas of corporate law: fiduciary duties, corporate governance and takeover bids. I will show how the conduct of corporate actors in these areas is in significant part a result of social norms, and will examine the bearing of legal rules on social norms in these areas.

\section{A. Fiduciary Duties}

The major fiduciary duties of corporate actors are the duty of care and the duty of loyalty. The duty of care concerns the standards that apply to the conduct of corporate actors who are free of self-interest. My theses concerning the duty of care are as follows: The level of directorial care is largely driven by social norms, rather than by the threat of liability or the prospect of gain. Within the last ten years, an inefficient nonobligational norm that licensed and insulated a low level of directorial care has been replaced by a more efficient obligational norm that requires a higher level of care. This norm-shift was in significant part the result of a change in belief-systems. The change in belief-systems, in turn, was partly induced by the expressive effect of legal authorities, which clarified and added moral force to the social norm of care.

The duty of loyalty concerns the standards that apply to the conduct of corporate actors who are not free of self-interest. My theses concerning the duty of loyalty are as follows: Adherence to the duty of loyalty is

26. American Law Institute, Principles of Corporate Governance: Analysis and Recommendations $\$ 2.01(\mathrm{~b})$ (1992) [hereinafter ALI, Principles of Corporate Governance].

27. 118 S. Ct. 1876 (1998).

28. 118 S. Ct. at 1888, n.13; see also id. at 1889 ("norms of corporate behavior . . . are crucial reference points .... in identifying the limits of the presumption that a dual officeholder acts in his ostensible capacity").

29. Id. 
driven by both the threat of liability and social norms. The legal rules in this area serve both regulatory and norm-supporting and norm-defining functions. Although the regulatory function of these legal rules is important, the social norm of loyalty that the legal rules support and define is critical to the efficient operation of the duty of loyalty.

Standards of care and loyalty potentially apply to all major types of corporate actors, although often in somewhat different ways to different actors. I will focus on the application of the duty of care to directors and the application of the duty of loyalty to directors and officers.

I. The Duty of Care. - The common experience of informed observers is that the level of directorial care has risen significantly in the last ten years or so; that directors today are more attentive to their responsibilities, more ready to displace inefficient CEOs, more concerned about corporate structure, more active in setting agendas and determining corporate strategy, and so forth. ${ }^{30}$

What has caused this shift to a greater level of care? Pretty clearly, not an increased threat of liability. It is true that during this period the meaning of the duty of care was greatly clarified and elaborated: Smith $v$. Van Gorkom made clear that reasonable inquiry by a director was a condition to the invocation of the business judgment rule. ${ }^{31}$ The ALI's Principles of Corporate Governance formulated the first clear statement of the business judgment rule as a special standard of review-that is, a rationality rather than a reasonability standard-and the conditions that had to be satisfied to qualify for application of the special standard of review..$^{32}$ Cede E Co. v. Technicolor, Inc. made clear that if the conditions to invoking the business judgment standard of review are not satisfied, the standard of review is reasonableness or some equivalent. ${ }^{33}$ The monitoring duty of the board was made explicit and strongly supported, first in Francis $v$. United Jersey Bank ${ }^{34}$ and later and more comprehensively in the Caremark case. ${ }^{35}$

From a liability perspective, however, the developments during this period were overshadowed, if not overwhelmed, by the adoption of director-shield statutes that permit a corporation's certificate of incorporation to eliminate the liability of directors for violation of the duty of care. Delaware Section 102(b) (7) is typical. This section provides that the certificate of incorporation may include:

30. See, e.g., Ira M. Millstein \& Paul W. MacAvoy, The Active Board of Directors and Performance of the Publicly Traded Corporation, 98 Colum. L. Rev. 1283, 1283-86 (1998). My claim lere is not that directors are now performing just as they should. See, e.g., Charles Gaparino and Pui Wing Tam, Mutual-Fund Boards: No Comfort?, Wall St. J., Feb. 5,1999 , at C1. Rather, my claim is that directorial performance has significantly improved.

31. 488 A.2d 858, 872-73 (Del. 1985).

32. ALl, Principles of Corporate Governance, supra note $26, \S 4.01$.

33. 634 A.2d 345, 360-61, 371-73 (Del. 1994).

34. 432 A.2d 814, 822-23 (N.J. 1981).

35. In re Caremark Int'l, Inc. Derivative Litig., 698 A.2d 959, 968-70 (Del. Ch. 1996). 
A provision eliminating or limiting the personal liability of a director to the corporation or its stockholders for monetary damages for breach of fiduciary duty as a director, provided that such provision shall not eliminate or limit the liability of a director: (i) For any breach of the director's duty of loyalty to the corporation or its stockholders; (ii) for acts or omissions not in good faith or which involve intentional misconduct or a knowing violation of law; (iii) [for improper distributions]; or (iv) for any transaction from which the director derived an improper personal benefit. ${ }^{36}$

The shield statutes have important exceptions. For example, the statutes typically do not apply to an officer acting in her capacity as an officer. This exception, however, does not affect directors acting in their directorial capacities. In addition, the statutes generally concern only liability, not the validity of directorial action, so that although the directors are protected against liability for an action, the action itself may be deemed invalid. There are many important contexts in which the standard of care may affect validity; among the most important are decisions by disinterested directors to approve interested-director transactions or to take defensive actions against a takeover bid. The validity exception, however, does not reduce the statutes' protection against liability.

The statutes also typically have exceptions, like those in Delaware Section 102(b) (7), for acts or omissions not "in good faith," or which involve "intentional misconduct," or the like. ${ }^{37}$ The meaning of these terms in this context will have to be developed by judicial interpretation, but a lot can be packed into the concept of good faith. In In re RRR Nabisco, Chancellor Allen stated that an action by a director is not in good faith if it is based on "any human emotion [that] may cause a director to place his own interests, preferences or appetites before the welfare of the corporation" including "hatred, lust, envy, revenge, . . . shame or pride." 38 In Gagliardi v. Trifoods International, Inc., Chancellor Allen stated: "I include within the category of improper motivation those cases in which particularized claims of director entrenchment are inade . . [o] $\mathrm{r}$ in which, relatedly, transfers of corporate control by the board ... are involved." 39 In Caremark, Chancellor Allen stated that "a sustained or systematic failure of the board to exercise oversight-such as an utter failure to attempt to assure a reasonable information and reporting system exists-will establish the lack of good faith." 40 The ineaning of "intentional misconduct" is also unclear. For example, a complete failure to act might be construed as intentional misconduct within the meaning of the statutes. The not-in-good-faith and intentional-misconduct excep-

36. Del. Code Ann. tit. 8, § 102(b) (7) (1991).

37. Id.

38. In re RJR Nabisco, Inc. Shareholders Litig., 14 Del. J. Corp. Law 1132, 1159 (Del. Ch. 1989).

39. Gagliardi v. Trifoods Int'l, Inc., 683 A.2d 1049, 1051 n.4 (Del. Ch. 1996).

40. Caremark, 698 A.2d at 971. 
tions therefore somewhat diminish the protection the shield statutes afford against directorial liability for breach of the duty of care. Even when these exceptions are taken into account, however, the result of the shield statutes is to drastically reduce the threat of such liability. Accordingly, if directorial care was based solely on the threat of liability we would expect the level of care to have gone drastically down in the last ten or so years, rather than significantly up.

A possible incentive for care even when there is no significant threat of liability is the prospect of individual gain. This factor, however, is insufficient to account for the increase in directorial care over the last ten or so years. To begin with, a director's compensation is normally unrelated to his performance. Such compensation is almost invariably uniform for all directors on a given board (subject perhaps to extra compensation for committee service). Extra care by a particular director is therefore unlikely to lead to increased compensation. A director might have an incentive to exercise care so that he will be reappointed or will be more attractive as a directorial candidate for other corporations, but few directors fail to be reappointed for lack of care and there is little or no evidence that there is a market in careful directors. Under very recent practice, directors may receive part of their compensation in the form of stock or stock options. Some believe that this practice will increase directorial care. That may or may not be true, but the practice is too new and too limited to account for the general increase in the level of directorial care over the last ten or so years.

Since the increased level of directorial care over the last ten or so years cannot be accounted for either by an increase in the threat of liability or by the prospect of gain, and since, indeed, the threat of liability has been substantially reduced if not virtually eliminated, it is difficult to avoid the conclusion that the level of directorial care is determined in significant part not by the threat of liability or the prospect of gain, but by social norms concerning the directorial role, and that the increased level of care is due to a shift in these social norms.

What has led to this shift? One factor may be the role of the media. The business press, like the general press, has become increasingly willing, and indeed eager, to report on the shortcomings of directors and officers. A juicy story about feckless directors on page one of the Wall Street Joumal is the equivalent of a picture of Brad Pitt on the cover of Vanity Fair. The increased likelihood of such stories, with their consequence of shaming and the loss of esteem, may have been one factor in making directors more attentive. Another factor is that directorial performance has come under closer scrutiny from institutional investors, who may either put direct pressure on directors or present another possible source of bad publicity.

But something more significant seems to be operating; that is, a shift in the social norm governing directorial duties, from a nonobligational practice norm that insulated inactive directors from criticism and self- 
criticism, to an obligational norm that requires a higher level of care. This shift in norms, in turn, largely resulted from a change in the beliefsystem of the business community concerning the nature of the obligations associated with the directorial role. The issue then is what elements led to this change in the belief-system. One possible element was new information. Some of this information was provided by the rise of the takeover-bid institution. The enormous discrepancy between takeoverbid prices and market prices conveyed the information that there was a lot of managerial inefficiency, and that something in addition to takeover bids needed to be done about it. The relative decline of such corporate giants as General Motors and Sears conveyed the same information.

The law may also have contributed to the change in directors' beliefsystems. Recall that at the same time the shield statutes virtually eliminated liability for the director's breach of the duty of care, the courts were greatly clarifying the meaning of that duty. ${ }^{41}$ To understand the impact of this clarification, a distinction must be drawn between standards of conduct and standards of review. A standard of conduct states how an actor should conduct a given activity or play a given role. A standard of review is the test a court applies when it reviews an actor's conduct to determine whether to impose liability or grant injunctive relief.

Typically, the elements of a standard of conduct and a correlative standard of review are the same. For example, the standard of conduct for an actor in driving a car is to drive carefully, and the correlative standard of review to determine whether liability should be imposed is whether the actor drove carefully. In corporation law, however, the standards of conduct and review pervasively diverge. ${ }^{42}$ For example, in the area of duty of care the standard of conduct is "act reasonably," but the standard of review is often the much looser business judgment standard of rationality. Similarly, the elimination of liability under the shield statutes did not affect the director's standard of conduct, but only the liability for failure to adhere to that standard.

Although legal standards of conduct are characteristically accompanied by liability rules or other enforcement regimes, even a legal standard of conduct that is unaccompanied by such a regime may be effective because of its impact on social norms. While social norms differ from legal rules, there is often a symbiotic relationship between legal rules and social norms. On the one hand, legal rules are often based on social norms. On the other hand, many legal rules have an expressive effectthat is, in addition to their regulatory effects, legal rules send messages of various kinds. ${ }^{43}$ Adoption of a legal rule that is based on a social norm sends a message that the community regards the norm as especially important. This message increases both the likelihood that the norm will be

41. See supra text accompanying notes 31-35.

42. See Melvin Aron Eisenberg, The Divergence of Standards of Conduct and Standards of Review in Corporate Law, 62 Fordham L. Rev. 437 (1993).

43. See Sunstein, Expressive Function of Law, supra note 2, at 2025-29. 
internalized and the reputational penalties for violating the norm. Furthermore, legal rules add, to the force of a specific obligational norm, the force of the general norm of obedience to law, which is one of the most powerful norms of our society.

Legal rules may also serve to clarify social norms by providing focal points for their meaning. ${ }^{44}$ The clarifying function of legal rules has obvious relevance to the duty of care, because one function of the cases that clarify the meaning of that duty, especially in a directorial context, is to tell directors how to play their directorial role. Thus one way of looking at the change in the social norm concerning directorial care is that directors who once believed, as a result of an earlier prevailing practice, that they could properly satisfy the demands of the directorial role with minimal attention, have been instructed by the courts-or perhaps more accurately, by their lawyers-that this view is wrong. Having been so instructed, directors who wanted to perform their role properly made appropriate adjustments in their conduct-not necessarily to avoid liability, but just because they wanted to play their roles properly. Ed Rock, in a notable article, shows how much of the Delaware case law on takeovers, and by extension the duty of care generally, can be understood as directed in significant part toward instructing directors on how to play their role in that context and publicly admonishing those directors who failed to properly play that role. ${ }^{45}$

Legal rules may also be effective, even without an enforcement strategy, because they facilitate the effectiveness of informal sanctions by norm-compliers against norm-violators. For example, Cooter points out that if smoking in public places like airports violates a social norm but not a legal norm, some norm-compliers will attempt to enforce the norm by sanctioning smokers with words or looks, but others will not. If a legal rule is adopted to ban smoking in such places, many of the norm-compliers who previously had kept silent will now speak out. ${ }^{46}$ This effect may be especially inportant where a relatively small number of additional informal norm-enforcers unay tip the balance in a way that makes norm violations too uncomfortable to be worth the trouble. Correspondingly, the adoption of a legal rule, even without formal enforcement, can cause actors to correctly believe that there will be more social enforcement of the norm. ${ }^{47}$ This aspect of the effect of legal rules on social norms is

44. See Cooter, Expressive Law and Economics, supra note 2.

45. See Edward B. Rock, Saints and Sinners: How Does Delaware Corporate Law Work?, 44 UCLA L. Rev. 1009 (1997).

46. See Cooter, Decentralized Law, supra note 2, at 1673-74.

47. See id; see also Cooter, Expressive Law and Economics, supra note 2, at 595: Perhaps enacting a law forbidding wrongdoing, without enforcing the law, can induce 76 percent of the actors to do right. If most citizens obey the law from respect, enacting the law without enforcing it can probably achieve the desired result. I have suggested that prohibiting smoking in American airports and requiring dog owners to clean up after their anmuals ("pooper-scooper" laws) work this way. Most people began to obey these laws as soon as they became 
particularly salient to the duty of care, because the development of the meaning of that duty in the case law gave institutional investors, the media, and, for that matter fellow directors, a better purchase for criticism of laggard directors.

The history of the norms concerning the duty of care illustrates that nonobligational practice norms can have significant consequences. The prior social norm concerning the director's role was the nonobligational practice norm that directors do not do much. Although this norm was not obligational it had a significant effect on conduct, because it permitted a low level of directorial care by insulating directors who did not do much from both external criticism and self-criticism.

This history also illustrates that social norms may be inefficient. There is sometimes a tendency to view social norms as good, efficient, or both; in particular, to view social norms as a form of private action that does a better job of regulating conduct, just because it is private action, than governmental action. But social norms are not necessarily either good or efficient. They may be morally bad, or at least insulate morally bad conduct from criticism, as in the Jim Crow South. They may promote inefficient behavior, or at least insulate inefficient behavior from criticism, as did the prior social norm concerning the director's role.

Bad or inefficient social norms may result from a variety of causes, including self-interest, inertia, and bad or inefficient belief-systems. Bad or inefficient belief-systems, in turn, may result from bad information or from persuasion that is founded on false premises or developed by fallacious or incomplete reasoning. Whatever the origin, it is important that social norms not be treated as intrinsically more desirable than legal regulation in governing conduct. Rather, the issues raised by social norms, for those concerned about the law, are how social norms operate in a field that is within the scope of law; whether, in any given area, social norms potentially have advantages over legal rules in governing conduct; and whether the social norms that prevail in an area are good or bad, efficient or inefficient.

\section{The Duty of Loyalty.}

a. Authentic Loyalty and Instrumental Loyalty. - The duty of loyalty is a shorthand expression for the duty of fair dealing by, and the trustworthiness of, directors, officers, and controlling shareholders when they are financially interested in a matter affecting the corporation. A useful entry point into the relationship between law and social norms in this area is provided by an important article by Jonathan Macey and Geoffrey Miller. ${ }^{48}$ This article was triggered by the Supreme Court's decision in Basic, Inc. v. Levinson, ${ }^{49}$ which held that a corporation that denies that it

aware of them. For the small recalcitrant group of lawbreakers, rude remarks by citizens and other informal punishments deter without state coercion.

48. Jonathan R. Macey \& Geoffrey P. Miller, Good Finance, Bad Economics: An Analysis of the Fraud-on-the-Market Theory, 42 Stan. L. Rev. 1059 (1990).

49. 485 U.S. 224 (1988). 
is in merger negotiations violates Rule $10 \mathrm{~b}-5$ if the denial is false and the information is material. ${ }^{50}$ Macey and Miller criticize this result. They begin by arguing, as others have, that from an economic perspective, fiduciary principles are essentially contractual devices:

This economic perspective is important because it generates a mechanism by which courts can decide cases. In particular, when scrutinizing managerial behavior, courts should treat an allegation of a breach of fiduciary duty as they would treat any alleged breach of contract. This analytic method often is described as the "hypothetical bargain" approach. Under this approach to fiduciary duty, courts would evaluate whether the managers' actions were consistent with the terms of a hypothetical fully specified, contingent contract that informed, valuemaximizing investors would have agreed to ex ante. ${ }^{51}$

Based on this perspective, Macey and Miller argue that lies by corporate officials should be exempt from liability if they are made with the good faith intention of furthering the shareholders' interests, and do not create negative externalities and thereby reduce allocative efficiency. .52 Accordingly, Macey and Miller conclude, the issue that arose in Basic should have been resolved by asking whether a rational shareholder group would endorse a corporation's strategy of publicly and falsely denying that it was involved in merger negotiations. Based on this standard, Macey and Miller conclude that a corporation should be able to falsely deny that it is in merger negotiations, because nondisclosure facilitates merger negotiations, merger negotiations facilitate mergers, and mergers increase shareholder wealth. ${ }^{53}$

There are important problems with the Macey and Miller analysis even when the analysis is taken on its own terms. One of these problems is that if the Macey and Miller rule prevailed, then whenever a corporation made a statement, investors could not know whether the statement was true or was the kind of lie that would be permissible under the Macey and Miller rule. Since the Macey and Miller rule is not limited to statements concerning merger negotiations, investors would have to discount all corporate statements because they might be permissible lies. Discounting all corporate statements, however, would make the market significantly less efficient, if not positively inefficient, which would be bad

50. The Court added that materiality in a merger context depends on the probability that the merger will be consummated and its significance to the corporation if it is consummated. See id. at 238-39.

51. Macey \& Miller, supra note 48 , at 1068-69 (citations omitted).

52. See id. at 1075. An example of a lie that they say would not be permitted under this rule is a false statement that a corporation is involved in merger negotiations, where the purpose of the statement is to make it seem that the corporation is in play and thereby increase the likelihood of takeover bids. Here, potential bidders would waste resources in sifting through false information disseminated by the corporation.

53. See id. at 1058-76. 
for shareholders as a class. ${ }^{54}$ Moreover, unless a corporation can commit itself to honesty, under the Macey and Miller rule the corporation could not convincingly make a truthful statement that it was not engaged in merger negotiations-or for that matter, in any other rumored-but-untrue value-enhancing transaction.

The most fundamental problem with the Macey and Miller analysis, however, is that it ignores the expressive function of law. If the Macey and Miller rule was adopted, the message that the law would send is that there is nothing wrong with lying-that truth-telling is valued not for its own sake, but only instrumentally. Such a message would significantly diminish the force of the social norm of truth-telling. ${ }^{55}$ Just as the law can add to the force of an obligational norm by throwing its support to the norm, so it can reduce the force of an obligational norm by withdrawing support. Even if the result of sanctioning lies was good for shareholders in their shareholder role, it still would be bad for shareholders in their larger role as members of society.

There is also a strictly economic reason why the law should not send such a message. The corporate system operates most efficiently where corporate actors act loyally-that is, deal fairly and in a trustworthy manner-and are perceived to do so. One way to achieve loyalty is by legal sanctions. Taken alone, this way is very expensive and probably has limited effectiveness, because of the difficulty of detecting breaches of the duty of loyalty and the cost of legal enforcement. A second way to achieve loyalty is to install intracorporate monitoring and bonding systems. This way is somewhat more effective than a legal regime alone, but it is also very expensive-and the more effective it is to be, the more expensive it must be.

In contrast, the operation of the social norm of loyalty is very inexpensive. Of course, if the loyalty norm is adhered to only because the actor fears reputational sanctions, the problem of detection remains significant. Drawing on terminology used by Bruce Chapman, I will refer to loyalty that is based on an internalized norm-particularly a norm that shapes character-as authentic, and to loyalty that is based on reputa-

54. Another, related point is made by Ian Ayres. Assuming that a rule that permitted a corporation to lie would be a default rule, then a corporation could vary the rule by committing itself to honesty. If a corporation did not commit to honesty, the market would simply assume that any statements the corporation made were dishonest. This assumption, in turn, would induce a majority of corporations to commit to honesty, which would more or less bring us back to where we are now. See Ian Ayres, Back to Basics: Regulating How Corporations Speak to the Market, 77 Va. L. Rev. 945, 947-59 (1991).

55. It is true that under certain exceptional circumstances, a lie may be morally justified. For example, it may be morally justifiable to tell a dying person that he will recover, or to lie to a would-be murderer about the location of his intended victim. Such lies are justified, however, only because they are made to serve an independent moral purpose and for the benefit of a person other than the liar. A lie made for the instrumental purpose of increasing the liar's material gain, or the material gain of the liar's principal, cannot be morally justified. 
tional concerns as instrumental. 56 Instrumental loyalty is good, but authentic loyalty is better. Instrumental loyalty will be forthcoming only when disloyalty is easy to observe. Authentic loyalty will be forthcoming even when disloyalty is difficult to observe.

To put the extreme case, if all corporate actors fully internalized the social norm of loyalty and gave full effect to that norm, the costs of both legal sanctions and monitoring and bonding systems would be unnecessary, and the levels of loyalty would be much higher than those sanctions and systems can achieve. Accordingly, whatever the law does do to increase the force of the social norm of loyalty, and further its internalization, will lead to greater efficiency and will therefore benefit shareholders as a class. Whatever the law. does to diminish the force of the social norm of loyalty, and lessen its internalization, will have the opposite effect. Therefore, even taking the interests of shareholders as a class apart from their interests as members of society, a legal regime that promoted the view that the social norm of loyalty is only instrumental, and which thereby diminished both the force of the norm and its internalization, would reduce the efficiency of the corporate system.

What is true of the corporate system in particular is also true of the economic system in general. As stated by Casson:

Overall economic performance depends on transaction costs, and these mainly reflect the level of trust in the economy. The level of trust depends in turn on culture. An effective culture has a strong moral content. Morality can overcome problems that formal procedures-based on monitoring compliance with contracts-cannot. A strong culture therefore reduces transaction costs and enhances performance-the success of an economy depends on the quality of its culture. ${ }^{57}$

An analogous objection applies to the conception, adduced by Macey and Miller in support of their argument that the duty of loyalty is essentially contractual. The duty of loyalty is seldom, if ever, imposed by a real contract. Directors and officers do not agree that they will be bound by a duty of loyalty. Instead, the duty is imposed by law. As the Delaware Supreme Court said in Guth v. Loft, "[a] public policy, existing through the years, and derived from a profound knowledge of human characteristics and motives, has established a rule that demands of a corporate officer or director, peremptorily and inexorably, the most scrupulous observance of his duty . ..."58

It is true that the duty of loyalty, and the corresponding rights it creates, may be limited in certain respects by agreement. However, that a right or a duty may be limited by agreement does not make the right or

56. See Bruce Chapman, Trust, Economic Rationality, and the Corporate Fiduciary Obligation, 43 U. Toronto L.J. 547, 580 (1993).

57. Mark Casson, The Economics of Business Culture: Game Theory, Transaction Costs, and Economic Performance 3 (1991).

58. 5 A.2d 503, 510 (Del. 1939) (emphasis added). 
duty contractual. For example, the general duty to exercise reasonable care can be contracted around, within certain limits, ${ }^{59}$ but that does not make the law of negligence contractual. Similarly, the right to a jury trial can be waived, but that does not make the Sixth Amendment contractual. Nor is a right or a duty contractual because it is imposed on the basis of what courts or legislators believe the parties would want to do if they had addressed the issue. Since it is impossible to determine what terms actors with unknown preferences and potentially different bargaining power would actually agree upon, rules that purport to be based on hypothetical bargains are actually based on collective action. Furthermore, if the duty of loyalty was contractual, it would follow that the duty could be not only limited but completely waived by agreement. Generally speaking, however, it cannot be. ${ }^{60}$

A more fundamental problem with the contractual conception of the duty of loyalty is that the critical role of trust in the success of the corporate system would be significantly undermined if the law sent a message that the duty of loyalty was essentially a contractual duty, not a duty imposed by law. As Bruce Chapman has stated:

[C] ompetitive corporate contracting cannot achieve all that this [contractual] view promises unless it is aided by the very value that a contractual understanding of the fiduciary obligation denies, namely, the duty of loyalty and trust. Trust plays an essential role in all modern economies, and without it, or without the coordination that is provided by institutional loyalty, even efficient wealth-maximizing corporate contracting can make us all worse off .... Nor can the concept of trust be very easily accommodated into the contractual model of the corporation. Properly interpreted, the concepts of trust and loyalty present a deep challenge not only to that contractual model, but also to the very conventions of instrumental rationality upon which the model is based.61

In short, the duty of loyalty is almost never the result of a real contract, and the adoption by the legal system of the contractual conception

59. See Restatement (Second) of Torts $\S 496 \mathrm{~B} \& \mathrm{cmt}$. (1964).

60. See, e.g., Securities Act of 1933 \$ 14, 15 U.S.C. $\$ 77 n$ (1994) ("Any condition, stipulation, or provision binding any person acquiring any security to waive compliance with any provision of this subchapter or of the rules and regulations of the Commission shall be void"); Securities Exchange Act of 1934 \& 29(a), 15 U.S.C. \& 78cc(a) (essentially the same); Del. Code Ann. tit. 8, $\$ 102$ (b)(7) (1991) (authorizing certificate provisions that eliminate the liability of a director for duty of care, but not authorizing provisions that eliminate a director's liability for violations of the duty of loyalty, actions in bad faith, or for any transaction from which the director derived an improper personal benefit, and not authorizing provisions that eliminate the liability of an officer for any violation of fiduciary duty, including the duty of care); ALI, Principles of Corporate Governance, supra note 26 $\S 5.09$, cmt. d (1992); Tamar Frankel, Fiduciary Duties as Default Rules, 74 Or. L. Rev. $1209,1242-43$ (1995).

61. Chapman, supra note 56, at 549; accord Frankel, supra note 60, at 1266-71. 
of the duty of loyalty, like the adoption of an instrumental conception of truth-telling, would disserve efficiency interests.

b. Sanctions. - Another role of the social norm of loyalty is to up the ante for violating the duty of loyalty for those corporate actors who have not internalized the duty. Generally speaking, the legal sanctions for violating the duty of loyalty are inefficiently low. The primary legal sanctions are rescission and restitution. Normally, however, these sanctions merely put the fiduciary back to where he would have been if he had not violated his duty. Because not all violations will be detected, a fiduciary whose only objective was to maximize his wealth, and who only feared legal sanctions for violating the duty of loyalty, would have an incentive to violate the duty-for example, by taking a corporate opportunity, or dealing unfairly with the corporation in a self-interested transaction. If the violation is undetected, the fiduciary comes out ahead. If it is detected, the fiduciary is normally no worse off under the legal sanctions than he would have been if he had not violated his duty. Although additional legal sanctions are sometimes imposed-for example, loss of salary or punitive damages-these sanctions are atypical and it is therefore doubtful that the prospect of such sanctions, discounted by the likelihood that they will be imposed, change the picture that much.

Therefore, if the only reason for not violating the duty of loyalty was the prospect of a legal sanction, fiduciaries would regularly violate that duty. The social norm of loyalty, however, adds the sanction of loss of reputation to the legal sanctions. Because the legal sanctions are set at an inefficiently low level, the increase in sanctions provided by the social norm is necessary if the total sanctions for breach of the duty of loyalty are to approximate an efficient level. To put this differently, in the absence of the social norm of loyalty, the costs of enforcing the duty of loyalty would be prohibitively high. Either corporate law would need to systematically impose huge punitive damages in loyalty cases to effectively deter breach, or corporations would be required to incur huge monitoring costs, or both.

c. Concretization. - In the case of the duty of care, the present posture of the law is essentially to support the social norm of care with a legal standard of conduct that is unaccompanied by an enforcement strategy. In the case of the duty of loyalty, the legal rules are accompanied by an enforcement strategy. Thus, the legal rules in this area achieve their ends partly by regulation and partly by the support they give to social norms. The latter, expressive function of the legal rules in the loyalty area is analogous to the expressive function provided by many other legal rules. However, the expressive function of the legal rules of loyalty has a special cast, because those rules not only support the norm but make it operational and meaningful through concretization.

In this connection, McAdams draws a useful distinction between general norms, like "friends should be loyal," and concrete norms, like the obligations "to listen attentively to a friend's troubles, to water her plants 
when she is away, to drive her home when she is intoxicated," and so on. 62 "Narrow, concrete norms," he points out, "often define the meaning of a specific behavior by defining that behavior as complying with or violating an internalized abstract norm. Thus, an antilittering norm may work because a consensus arises that littering violates the internalized norm to be a "good neighbor." "63

Similarly, a general duty of loyalty is one thing; a web of specific duties that particularize the general duty is another. Few if any philosophers specialize in delineating the meaning of loyalty in the corporate context. Rather, it is the courts that have made the general principle of loyalty fully meaningful by spinning out the principle into specific rules governing such matters as the fairness of self-interested transactions, disclosure, corporate opportunities, the use of corporate assets, and so forth. Once these rules have been developed, they serve to support the social norm of loyalty in a variety of ways-for example, by giving clarity to the norm and by providing a focal point around which overlapping instantiations of the norm can cohere. These messages, in turn, are amplified by corporate codes of conduct and by stories in the business media that discuss particular transgressions. Thus, in the loyalty area the specific rules developed by courts simultaneously regulate the conduct of corporate actors, and are transmuted into social norms concerning the conduct of corporate actors.

The role of the law in developing specific social norms in the loyalty area is important in itself. It also bears on the evaluation of shareholder suits. For at least fifty years, shareholder suits have come under criticism based on cost-benefit analyses that purport to show that on average the financial benefits of such suits are less than their costs. ${ }^{64}$ There are a number of problems with these studies, ${ }^{65}$ but the most basic flaw is that in calculating benefits, these studies count only immediate financial benefits. This approach iguores two of the most important benefits of shareholder suits to shareholders as a class. The first and most obvious of these benefits is the deterrent effect of shareholder suits. The second and even more important benefit is that it is through shareholder suits that the specific legal rules of the duty of loyalty have been shaped. Those legal rules, in turn, have given specific meaning not only to the

62. McAdams, supra note 2, at 382 .

63. Id. at 383.

64. See, e.g., Franklin Wood, Survey and Report Regarding Stockholders' Derivative Suits (1944); Roberta Romano, The Shareholder Suit: Litigation Without Foundation?, 7 J.L. Econ. \& Org. 55 (1991).

65. See, e.g., William L. Cary \& Melvin A. Eisenberg, Corporations: Cases and Materials 1126-29 (7th ed. 1995); William L. Cary \& Melvin A. Eisenberg, Corporations: Cases and Materials 928-31 (6th ed. 1988); Rock, supra note 45. Rock calculated that during the period $1980-1990, \$ 160$ billion was spent on leveraged buyouts, while the cost of fifteen Delaware cases that developed specific norms to govern such transactions was only $\$ 17$ million, as measured by the total amount awarded to the plaintiffs' attorneys in these cases. See Rock, supra note 45, at 1099. 
legal duty of loyalty, but to the social norm of loyalty. The social norm, in turn, provides an extremely effective and low-cost way to achieve loyalty. Thus shareholder suits, whatever their short-term purpose and result, have the long-term result of creating an extremely valuable public good. The desirability of such suits cannot be measured without counting the value of that good.

\section{B. Corporate Governance}

I now turn to issues of corporate governance, first at the management level and then at the ownership level. In each of these areas there has been a relatively sudden shift in the governing norms: in the former area, from a managing board to a monitoring board; in the latter area, from passivity to activity on the part of institutional shareholders. Each of these shifts in norms resulted in significant part from a change in the belief-systems of the relevant corporate actors, and each illustrates the manner in which norms can shift relatively suddenly when a tipping-point is reached.

1. The Monitoring Board. - Until about twenty years ago, the dominant model of the board was that the board was responsible for managing the business of the corporation. ${ }^{66}$ This model was hopelessly unrealistic, because part-time directors cannot manage the business of, or even set business policy for, a complex enterprise. ${ }^{67}$

The managerial model of the board has now been supplanted by a monitoring model. The monitoring model recognizes that in a publicly held corporation the management function is exercised by the senior executives. Under the monitoring model, therefore, the primary function of the board of a publicly held corporation is not to manage the business of the corporation, but to select, regularly evaluate, fix the compensation of, and, where appropriate, replace the senior executives, and to monitor the conduct of the corporation's business to evaluate whether the business is being properly managed. ${ }^{68}$

This functional component of the monitoring model is complemented by a structural component. If the board has the function of monitoring the senior executives, it must be structured to effectuate that function. Effectuating that function requires that the board consist of at least a majority of directors who are independent of the senior executives, and that the board have audit, nominating, and compensation committees composed exclusively of such independent directors. ${ }^{69}$ I will refer to boards that have this structure and perform the monitoring function as monitoring boards.

66. See Melvin A. Eisenberg, The Structure of the Corporation 139 (1974).

67. See id. at $140-48$.

68. See, e.g., ALI, Principles of Corporate Governance, supra note 26, $\$ \S 3.01,3.02$.

69. See, e.g., id. \$§ 3.05, 3A.02-.05. 
Today, the monitoring model of the board has been almost universally accepted and adopted in large publicly held corporations. ${ }^{70}$ Ultimately, the acceptance and adoption of the monitoring model of the board rests on its perceived economic advantage in providing an additional system to monitor the efficiency of management-in particular, of the CEO. The monitoring board, taken alone, is an imperfect mechanism to achieve that end, but because all systems to monitor the efficiency of the management of publicly held corporations are imperfect, it is important to construct a web of overlapping and even redundant monitoring systems. The monitoring board is one important part of that web.

The monitoring model would have made as much economic sense twenty years ago as it does today. The significant question therefore is not why the monitoring model has been widely accepted and adopted, but why has it only recently been widely accepted and adopted-that is, why a social norm that is efficient now, and would have been efficient then, was not adopted then. As in the case of the duty of care, the answer in large part is that there was a change in the belief-systems of the relevant actors. The business community, the investment community, the profession, and the bench came to believe that the monitoring model was important, and acted accordingly.

To begin with, the business community accepted the monitoring model. Thirty years ago, many prestigious corporations had only a minority of independent directors, and the audit and especially the nominating committee were still in their early days. Now, the situation has completely turned around. The business community's widespread acceptance of the model is evidenced not only by actual practice, but by that community's statements of best practice. For example, the Business Roundtable has issued two statements on corporate governance that include strong endorsements of the monitoring model. ${ }^{71}$ At this point, the monitoring model is not only endorsed by the business community but virtually taken for granted.

70. For example, a recent study found that among corporations with a market capitalization of $\$ 10$ billion or more, the average percentage of independent directors on the board was $66 \%$. Even among corporations with a market capitalization of only \$250-500 million, the average percentage of independent directors on the board was $58 \%$. See Russell Reynolds Associates, 1997-1998 Board Practices Survey 9 thl.2 (1998). Among corporations with market capitalization of $\$ 10$ billion or more, all had audit and compensation committees, and $93 \%$ had nominating committees. The average percentage of imdependent directors on the audit committee was $82 \%$; on the compensation committee, 93\%; and on the nominating committee, 79\%. See id. Even among corporations with a market capitalization of $\$ 250-500$ million, $100 \%$ had audit committees, $98 \%$ had compensation committees, and $53 \%$ had nominating committees. The average percentage of independent directors on the audit committee was $80 \%$; on the compensation committee, $82 \%$; and on the nommating committee, $53 \%$. See id.

71. See Business Roundtable, Statement on Corporate Governance 4-16 (Sept. 1997); Busmess Roundtable, Corporate Governance and American Competitiveness, 46 Bus. Law. 241, 246-48 (1990). 
Similarly, the investment community came to believe in the economic value of monitoring boards, and began to put pressure on corporations that did not adopt it. Boards that do not adopt the monitoring model are subjected to severe criticism by institutional investors and are publicly derided in forums like Business Week's list of the twenty-five worst boards, CaIPERS's annual list of underperforming companies, and a similar list issued by the Council of Institutional Investors.72

The profession also came to believe in the efficiency of the monitoring board, and transmitted that belief to the business community, partly through the AII's Principles of Corporate Governance ${ }^{73}$ and the ABA's Corporate Director's Guidebook. ${ }^{74}$

Finally, decisions of the Delaware courts over the last fifteen or twenty years provided an incentive for adopting the monitoring model, by making clear that in duty of care, duty of loyalty, and takeover cases very heavy weight would be put on process considerations, and that the structure of the board, and the way that structure found expression in the particular case, was a very important process consideration. Indeed, many of the Delaware cases in the last fifteen or twenty years concerning the duty of care, the duty of loyalty, and takeover bids can be viewed in significant part as corporate-governance cases. ${ }^{75}$

It could be argued that the stimulus of avoiding liability, rather than a change in belief-systems, caused the shift in board norms. Certainly the regulatory aspects of these cases contributed to the adoption of the new norm, but it is not a full explanation. The criticism that institutional investors and the media level at corporations that have not adopted the monitoring model is not based on liability concerns. The promotion of the monitoring model by the Business Roundtable, the ABA, and the ALI is not based on liability concerns. Furthermore, an explanation of the new norm based solely on the regulatory effect of Delaware decisions would fail to explain what led the Delaware courts to reach these decisions. Judicial decisions do not drop from the clouds. They are, to a significant extent, the product of the same belief-systems that motivate private actors.

What then caused the change in belief-systems concerning board function and structure? Partly the relevant communities were persuaded

72. See John A. Byrne, The Best and the Worst Boards, Bus. Wk., Dec. 8, 1997, at 90; Calpers Releases List of Nine Corporate America's Poorest Financial and Economic Performers (visited Apr. 23, 1999) <http://www.ca.gor/whatsnew/press/1999/ 1421a.htm>; Council of Institutional Investors' Home Page, (visited Apr. 23, 1999) <http:/ /www.ciicentral.com>; see also Timothy D. Schellhardt, More Directors are Recruited from Outside, Wall St. J., Mar. 20, 1991, at B1.

73. ALI, Principles of Corporate Governance, supra note 26, $\$ \$ 3.01,3.02$.

74. ABA Section on Business Law, Corporate Director's Guidebook, 49 Bus. Law. 1243, 1257-74 (1994).

75. See, e.g., Kahn v. Tremont Corp., 694 A.2d 422 (Del. 1994); Mills Acquisition Co. v. McMillan Co., 559 A.2d 1261 (Del. 1989); Smith v. Van Gorkom, 488 A.2d 858 (Del. 1985); Weinberger v. UOP, Inc., 457 A.2d 701 (Del. 1983). 
by a new idea. Not too long ago, the dominant idea was that the board had the function of managing the business of the corporation, not of monitoring management. The business community, the investment community, the bar, and the courts became persuaded that the new monitoring idea was markedly better than the old managing idea.

In addition, the information concerning managerial efficiency that was transmitted by the spread between takeover-bid prices and market prices, which seems to have affected directors' belief-systems concerning the duty of care, probably also affected their belief-systems concerning the functions and structure of the board.

It might be objected that acceptance of the monitoring model did not result from a change in belief-systems, but from new efficiency considerations. Such an objection would be hard to sustain. One possible story would be that until twenty years ago all managements were highly efficient and a monitoring board was therefore unnecessary. Then managers became inefficient and a monitoring board became necessary. This story seems highly unlikely.

Another possible story would be that the institution of takeovers, coupled perhaps with an upsurge in foreign competition, required corporations to be managed more efficiently than they had been before. But that would not be a story showing that the monitoring board was unnecessary twenty years ago. Instead, it would be a story that inefficiencies that were tolerated up to twenty years ago were no longer going to be tolerated. That story would leave us where we started from: A norm that is efficient now, and would have been equally efficient then, was not adopted then.

An important implication of this history is that it suggests that the corporate governance structures in place at any given time are not necessarily the most efficient structures. This implication is in line with recent work by Mark Roe, ${ }^{76}$ Michael Klausner, ${ }^{77}$ Marcel Kahan, ${ }^{78}$ Jody Kraus, ${ }^{79}$ and others on elements such as path dependence, network externalities, and the theory of cultural evolution. However, the problem does not reflect only those elements. Board structure involves a significant conflict of interest, because a CEO will normally prefer not to be monitored. It took a certain amount of weight on the other side of the scale to overcome this conflict-of-interest preference. This weight needed to build up until it reached a tipping-point, through the accumulation of changes in belief-structures, and outside pressures that were themselves based on

76. Mark Roe, Chaos and Evolution in Law and Economics, 109 Harv. L. Rev. 64 (1996).

77. Michael Klausner, Corporations, Corporate Law, and Network, of Contracts, 81 Va. L. Rev. 757 (1995).

78. Marcel Kahan \& Michael Klausner, Standardization and Innovation in Corporate Contracting, 83 Va. L. Rev. 713 (1997).

79. Kraus, supra note 2. 
those changes. Once the tipping-point was reached, the result was a relatively sudden widespread acceptance and adoption of the new norm.

The monitoring-board model is an obligational norm, in that publicly held corporations that deviate from the model are subject to criticism. It is, however, an unusual kind of obligational norm. On its face, it seems to apply to institutions rather than to individuals. Furthermore, most obligational norms involve interactions between actors. In contrast, on its face the obligation of the monitoring-board norm seems to concern only how the corporation should organize itself, rather than how it should interact with other actors.

The apparently paradoxical nature of this norm, and of other comparable institutional norms, can be resolved in two steps. The first step is to disaggregate the corporation into managers (including, for this purpose, directors) and shareholders. The second step is to invoke the obligational norm that managers should manage the corporation in the interests of the shareholders. If it is accepted that the monitoring board is an important instrument to serve the interests of the shareholders, then directors who fail to adopt the monitoring model have violated the latter, individual obligational norm.

Now that the monitoring model has been accepted as a norm, we can observe a cluster of other, evolving norms that rest on the foundation of that model. Some of these norms are well along in the evolutionary process and have either taken hold or are taking hold. Others are in early stages, and may or may not flourish. One of these emerging norms is the treatment of the body of independent directors as a de facto corporate organ. For example, the General Motors Board Guidelines provide that the outside directors of the board will meet in executive session three times each year and that decisions on matters of corporate governance presumptively will be made by those directors. ${ }^{80}$ The CalPERS Core Guidelines also call for the independent directors to meet periodically as a group. ${ }^{81}$ The ALI's Principles of Corporate Governance provide that independent directors acting as a body are entitled under certain circumstances to retain legal counsel, accountants, or other experts, at the corporation's expense. ${ }^{82}$ A related emerging norm is the concept of a lead outside director, which is adopted, for example, in the GM and CalPERS Guidelines. ${ }^{83}$ Still another emerging norm is that the board of directors

80. See GM Board Guidelines on Significant Corporate Issues, para. 11 [hereinafter GM Guidelines].

81. See CalPERS U.S. Corporate Governance Core Principles and Guidelines 4 (April 13, 1998) [herinafter CalPERS Guidelines].

82. See ALI, Principles of Corporate Governance, supra note $26, \S 3.04$.

83. See GM Guidelines, para. 2; CalPERS Guidelines at 5, App. A. 
is responsible for the existence, integrity, and efficacy of the corporation's internal control system. ${ }^{84}$

2. Institutional Investors. - I now turn to developments in governance at the shareholder level. The most important development at this level is the dramatically increased activity of institutional investors. Twenty or thirty years ago, the basic norm that governed institutional participation in corporate governance was a passivity norm, reflected in part in the Wall Street Rule: If you don't like management, sell; if you don't sell, support management. Under the passivity norm, taking sides against management-voting against management proposals, supporting shareholder proposals, selling into tender offers, and so forth- "was not done."

To a certain extent, the passivity norm reflected an efficiency element: Collective action by dispersed shareholders was difficult to achieve, and if some but not all shareholders were active, they would bear all the costs while the passive free-riding shareholders would participate in the benefits.

However, it is easy to overemphasize this element. Many issues that come before shareholders require little cost to evaluate. And some issues come before shareholders in a recurring way-for example, proposals concerning anti-takeover provisions-so that the effort required to analyze the first such proposal can be amortized over a number of like proposals. The passivity norm was driven not only by an efficiency element, but by conflicts of interest on the part of institutional investors. For example, Bank $B$, which holds stock in Corporation $C$ as a trustee, may also have, or seek to have, a commercial relationship with Corporation $C$. That actual or potential relationship would be jeopardized if $B$ voted its $C$ stock against a position taken by $C$ s management. The passivity norm also reflected a cultural attitude. The managers of institutional investors were themselves managers, and siding with managers came more naturally to them than siding with shareholders.

In contrast to the time, not that long ago, when the dominant norm was one of passivity, today institutional investors, or many of them, stand ready to and periodically do vote against management proposals and for shareholder proposals, are willing to sell into tender offers, often pressure management to take specific actions, and sometimes act to achieve changes at the top inanagement level. I will refer to this mix of conduct as the activity norm.

Like the shift from the managing board to the monitoring board, the shift from the passivity norm to the activity norm arose for efficiency reasons. Indeed, institutional activity is itself a form of monitoring-shareholder monitoring of corporate structures, management proposals, and managers. Institutional monitoring, like board monitoring, is imperfect,

84. See Melvin A. Eisenberg, The Board of Directors and Internal Control, 19 Cardozo L. Rev. 237 (1997). 
but it is important because of the need for overlapping systems when each system is imperfect.

But why is the norm of institutional activity only a recent phenomenon? To some extent, the shift in norms can be accounted for by legal and economic developments. On the legal side, in the 1980s the Department of Labor, which administers ERISA and therefore has jurisdiction over pension funds, issued various letters and interpretive bulletins that made it clear that the fiduciary duties of trustees who manage pension fund assets include not only investment decisions but voting decisions. ${ }^{85}$ This position had a direct bite on pension fund managers. It also had an indirect bite on mutual fund managers, because those managers too have fiduciary obligations. ${ }^{86}$

On the economic side, a number of developments have lowered the cost of institutional activity. One of these developments is an increase in institutional shareholdings. ${ }^{87}$ Another is the creation and growth of infrastructures that facilitate institutional activity. Chief among these infrastructures are research-and-analysis and proxy-advisory organizations, such as Investors Responsibility Research Center (IRRC) and Institutional Shareholders Services (ISS). These organizations provide a variety of services to institutions, including analysis of the subject matter of issues that are up for a vote and advice on voting. The development of this kind of infrastructure institution has allowed institutional investors to form a kind of de facto research-and-analysis coalition by pooling their funds through the fees they pay to these organizations. This infrastructure therefore reduces the cost of making voting decisions and reduces free riding. Furthermore, portfolio corporations must be sensitive to the views of these organizations in formulating management proposals and dealing with shareholder proposals.

A second kind of infrastructure is the Council of Institutional Investors (CII), an organization of institutional investors. CII addresses investment issues that affect the size or security of pension fund assets. It allows institutional investors to form de facto coalitions to address substantive interests of common concern, such as board and committee composition and functions, dual-class voting structures, takeover defenses, and the structure of compensation arrangements. CII reduces the collective-action and free-rider problems by coordinating or representing member institutions when such issues become salient in particular portfolio corpo-

85. See Letter from Alan D. Lebowitz, Deputy Assistant Secretary, Department of Labor, to HeImuth Fandl, Chairman of the Retirement Board, Avon Products Inc. (Feb. 23, 1988), reprinted in 15 Pen. \& Ben. Rep. (BNA) 391 (Feb. 29, 1988) (often referred to as the Avon letter); Letter from Alan D. Lebowitz, to Robert A.G. Monks, Institutional Shareholder Services, Inc., (Jan. 23, 1990), reprinted in 17 Pen. \& Ben. Rep. (BNA) 244 (Jan. 29, 1990) (often referred to as the ISS letter); Interpretive Bulletin 94-2, 29 C.F.R. Part 2309 (1994).

86. See Investment Company Act of 1940 \$ 36, 15 U.S.C. $\$ 80 a-35$ (1994).

87. See, e.g., New York Stock Exchange, Shareownership 1995, at 26-27 (Table 12) (1995) [hereinafter Shareownership 1995]. 
ration. The bulk of CII's membership consists of public-pension and labor-pension funds, but some very large private-pension funds, such as the Coca-Cola and McDonald's funds, are also members. ${ }^{88}$

A third kind of infrastructure consists of shareholder-proposal entrepreneurs, who provide focal points for tacit coalitions of institutional investors. Shareholder-proposal entrepreneurs, such as lnvestors Rights Association of America, are skilled at crafting proposals that are designed to, and do, attract a coalition of institutional investors. ${ }^{89}$ The beauty of this kind of infrastructure, from an institutional-investor point of view, is that the coordination is more implicit than explicit. Accordingly, if a shareholder proposal can be crafted that will attract a number of institutional votes, institutions can coordinate at extremely low cost without directly communicating.

On another front, the 1992 Amendments to the Proxy Rules made it less expensive for institutional shareholders to stake out public positions and to communicate with each other. ${ }^{90}$ As a result of these amendments, in 1993 The Economist reported that in

this year's lone battle of any consequence-[the fight to separate the jobs of chief executive and chairman at Sears, Roebuck-] United Shareholders Association, a group of small shareholders plans to contact the company's 1,000 largest shareholders, who have around $70 \%$ of the votes. This will cost $\$ 5,000-10,000$. Under the old SEC rules, which obliged the association to contact all shareholders if it lobbied more than ten, the exercise would have cost $\left[\$ 1\right.$ million].$^{91}$

In short, the shift from the passivity norm to the activity norm can be explained in part on the basis of liability and economic developments. However, these elements do not seem sufficient, taken alone, to explain the shift. For example, the Department of Labor's efforts in this area, while significant, have not been accompanied by an important enforcement regime, and in any event directly affect only certain kinds of institutional investors. Similarly, the provision of new infrastructures can be seen as an effect, as well as a cause, of an increased willingness on the part of institutions to be active. And although it is true that the percentage of publicly held stock held by institutional investors has increased, this increase is not as dramatic as is often thought. Data on the percentage of stock held by institutional investors varies somewhat from source to source. I will use the Federal Reserve Flow of Funds Accounts as reported by the New York Stock Exchange in its booklet Shareownership 1995. According to this data, institutions held approximately $50 \%$ of all corporate

88. See the CII's home page (visited Apr. 23, 1999) <http://www.ciicentral.com〉.

89. See Investors' Rigths Association of America (visited Apr. 23, 1999) <http:// www.iraa.com/index.html>.

90. See John Coffee, Jr., The SEC and The Institutional Investor: A Half-Time Report, 15 Cardozo L. Rev. 837, 840-41 (1994).

91. American Corporate Governance: The Shareholders Call The Plays, The Economist, Apr. 24, 1993, at 83. 
stock in 1987, around the time when the norm began to shift, and this figure stayed fairly constant thereafter. But in 1974, twenty-five years ago, the proportion of corporate stock held by institutions was only $20 \%$ less than the 1987 level- $41 \%$ rather than $50 \% .{ }^{92}$ And as far back as 1969, institutions held $31 \%$ of corporate stock. ${ }^{93}$ Moreover, these figures understate the amount of publicly held stock held by institutions, because they represent the percentage of all stock held by institutions, not merely the percentage of publicly held stock held by institutions. For example, in December 1994 the Flow of Funds estimate for the market value of corporate equity was $\$ 6.049$ billion. The value of closely held stock accounted for approximately $\$ 1.2$ billion, ${ }^{94}$ or $20 \%$, of that amount. "If, as seems likely, non-traded equity is held primarily by individuals, the Flow of Funds data may yield an [underestimate] of the fraction of traded stock held by [institutions]. ${ }^{295}$ Thus in a study of institutional holdings of stock listed on the New York Stock Exchange, the Exchange estimated that as far back as 1974, institutions owned half of all such stock. ${ }^{96}$

To fully explain the shift in the norm, therefore, several other elements must be added to the mix. One such element is the rise of the takeover institution. In the face of tender offers at prices well above the market value of portfolio stocks, institutional investors who had always sided with management often found themselves opposing management. Once the passivity norm was breached in this way, it became easier to breach in other ways.

Another element is a change in the demography of institutional investors, consisting of a dramatic rise in the relative percentage of institu-

92. See Shareownership 1995, supra note 87 , at 25-26 tbl.12 (1995). See also James M. Poterba \& Andrew A. Samwick, Brookings Papers on Economic Activity 2, at 295, 310-19 (1995). 1 use here the Exchange's "unadjusted" Flow of Funds data. The Exchange's "adjusted" data removes nonprofit holdings from the household sector to the institutional sector, but adds back from the institutional sector to the household sector the holdings of bank trust departments, defined-contribution pension plans, mutual funds held by individuals and bank trust departments, and equity held in variable annuities. Shareownership 1995, supra, at 28. In effect, the adjusted data attributes assets held by certain kinds of institutions to individuals who have indirect interests in those assets. That adjustment might be relevant in determining how individuals hold their wealth, but the unadjusted data is more meaningful for present purposes, because it is based on the value of stock that institutional investors control.

93. See Poterba \& Samwick, supra note 92 , at 26.

94. See Poterba \& Samwick, supra note 92, at 312 n.25.

95. Shareownership 1995, supra note 87 , at 27.

96. New York Stock Exchange, 1975 Fact Book 53 (1975). Data assembled by the Conference Board reports a lower level of percentage of total stock held by institutions, but the rate of change is not that different. For example, the Conference Board reports $44 \%$ institutional ownership in 1988, against Federal Flow of Funds institutional ownership of $49 \%$, and $34 \%$ institutional ownership in 1980, against Federal Flow of Funds institutional ownership of 39\%. Compare The Conference Board, 2 Institutional Investment Report 39, tbl.14 (June 1998) with Shareownership 1995, supra note 87, at 26-27 tbl.12 (1995). 
tional shareholdings held by public-pension funds. ${ }^{97}$ The passivity norm reflected both the conflicts of interests of institutional investors and the cultural attitudes of their managers. Although the public-pension funds are not completely free of conflict-of-interest problems, their conflicts of interest are much less severe than the conflicts of most other institutional investors, and the cultural attitudes of their managers are not the same as those of private institutional managers As a result, the public-pension funds are able to get out in front on wealth-enhancing issues. Managers of more conflicted institutional investors, who might be uncomfortable getting out in front, often feel less discomfort in following behind. Thus the leadership of public-pension funds sparks what Jeff Gordon has aptly called the latent activism of other institutional investors. ${ }^{98}$

At the same time, the expressive effect of the Department of Labor's letters and interpretive bulletins made the passivity norm hard to justify. Managers of many institutional investors also became persuaded that at least some actions at the shareholder level, such as the elimination of poison pills or the rejection of poorly designed mergers, could add value to portfolios.

Critical mass was also a factor. When institutional investors believed that most other institutional investors would be passive, taking an active posture might have been viewed as a quixotic and wasteful gesture. However, once institutional investors came to believe that many other institutional investors would be active, taking an active posture could be viewed as a meaningful act that would help enhance portfolio values. Furthermore, as institutional investors switched from a passivity norm to an activity norm it became harder for corporate managers to threaten retaliation against active institutions. The weight of liability and economic changes, coupled with changes in belief-structures and the accretion of a critical mass, built to a tipping-point that moved institutional investors relatively quickly from the passivity norm to the activity norm. ${ }^{99}$

\section{Hostwe TAKEOVERS}

I turn, finally, to the area of hostile takeover bids. This area illustrates how even an exceptionally inefficient norm can shape corporate

97. See, e.g., Carolyn Kay Brancato, Institutional Investors and Corporate Governance 24 (Theodor Baums et al. eds., I997); New York Stock Exchange, 1996 Fact Book 83 (I997) (Table of holdings of corporate equities in the U.S.).

98. See Jeffrey N. Gordon, The Shaping Forces of Corporate Governance in the United States, 31 U. Rich. L. Rev. 1473, 1789 (1997).

99. The norms governing the subject-matter of institutional-investor interest have also changed significantly in the last twenty years. Institutional investors first moved to inore active voting decisions. Next, they moved to assessing corporate governance structures. The latest move has been toward assessing management and management policies. The change in the subject-matter of institutional-investor interest, in turn, has been accompanied by a change in the modalities through which these interests are expressed. Proactive consultation has come to join shareholder voting and purely reactive consultation. 
conduct. It also illustrates the way in which under appropriate conditions even a single defection from a norm can so disturb an underlying equilibrium that a new norm is created virtually overnight.

Until the mid-1970s, hostile takeovers were not of overarching significance. After that time, the institution of hostile takeovers exploded and, in tandem with increased foreign competition and drastic changes in information technology, significantly altered the manner in which American businesses were managed. What caused the change?

Hostile takeovers were far from unknown before the mid-1970s. Indeed, by that time they were regulated on the federal level by the Williams Act, which had been adopted in 1968. ${ }^{100}$ Until the mid-1970s, however, the social norms of the business, financial, and legal establishment were strongly opposed to hostile takeovers. In general, establishment corporations would not make hostile takeover bids, establishment investment bankers would not assist in hostile takeover bids, establishment commercial banks would not finance hostile takeovers bids, and establishment law firms would not represent hostile takeover bidders. Accordingly, until the mid-1970s hostile takeovers were normally engaged in and aided only by nonestablishment players, such as law firms consisting of lawyers whom establishment law firms had cast off or would not hire because of discriminatory norms.

The norms concerning hostile takeovers were not economically justified. Hostile takeovers could increase the wealth of shareholders, investment banks, commercial banks, and law firms. Even the threat of hostile takeovers could increase the efficiency of firms that were not targets but were afraid they might be. There was, however, one prominent group whose wealth, or at least whose position, was threatened by the prospect of hostile takeovers: corporate managers. Accordingly, it was in the selfinterest of corporate managers to subscribe to the norm that hostile takeovers were not done. Establishment investment banks, commercial banks, and law firms adhered to the norm partly because they were concerned that they would lose corporate business if they were perceived as norm-violators, and partly because as members of the establishment they internalized the norm.

The equilibrium was changed, and the norm shifted, as a result of several linked events in the mid-1970s. In 1973, United Technologies wanted to acquire ESB, a battery company (formerly known as Electric Storage Battery) whose technologies were compatible with those of United. ESB turned United away. United, following the then-prevailing norm, did not attempt a hostile takeover bid. In 1974, however, International Nickel (Inco) did make a hostile takeover bid for ESB. ${ }^{101}$ Inco was a member of the corporate establishment. Perhaps more important, a

100. Williams Act, Pub. L. No. 90-439, 82 Stat. 454 (codified as amended at 15 U.S.C. $\S \S 78 \mathrm{~m}(\mathrm{~d})-(\mathrm{e}), 78 \mathrm{n}(\mathrm{d})-(\mathrm{f})$ (1994). (1987).

101. See John Brooks, The Takeover Game (1987); Jeff Madrick, Taking America 
premier investment bank, Morgan Stanley, decided to break ranks and assist Inco's hostile bid. The story is told as follows by Ron Chernow in his book, The House of Morgan:

[In the early 1970s, corporate] restructuring was still curbed by Wall Street etiquette, which frowned on unsolicited takeovers. Afraid of conflicts with clients, Morgan Stanley had a rule against hostile takeovers. In 1970, it nearly engaged in its first hostile bid when Warner-Lambert decided to take over part of Eversharp's shaving business; in that case, the mere threat of a hostile takeover made the target submit. So Morgan Stanley's taboo-breaking hostile raid was postponed until 1974, when International Nickel (Inco) pursued the Philadelphia-based ESB, formerly called Electric Storage Battery.

***

[T] he auspices [of Inco's bid] shocked Wall Street, for Inco was a conservative, blue-chip firm and Morgan Stanley was the official custodian of the Gentleman Banker's Code.

$* * *$

The nearly forty Morgan Stanley partners ... debated whether to spurn Inco or defy a code that had governed the world of high finance for almost 150 years.

$* * *$

The argument of inevitability was probably the decisive one. As one partner recalls, "The debate was, if we don't do what our clients want, somebody else will."

*** *

Frank Petito [Morgan Stanley's chairman] figured out how to twist the desecration of tradition into seeming veneration: in obliging Inco, the firm would simply be honoring an old Morgan tradition of serving faithful clients. But Petito had enough qualms about what they were doing to cast the upcoming Inco raid as an exception. A compromise was forged: the bank, in future, would engineer hostile raids only for existing clients and would fully warn them of unpleasant consequences. This, of course, didn't rule out much business. Morgan Stanley's large clients were just the sort that would now want to conduct raids, and they would know all about the unpleasant consequences. The compromise mostly reassured the firm's clients that it wouldn't be coming after them. ${ }^{102}$

The qualifications that Petito put on Morgan Stanley's willingness to assist in hostile takeover bids underline the extent to which Morgan Stanley was transgressing the then-prevailing social norm, and its desire to put a spin on its conduct that would soften this reality of the transgression. The ensuing interaction between Morgan Stanley and its lawyers speaks to still another, related, social norm:

102. Ron Chernow, The House of Morgan 596-99 (1990). 
At this juncture, Morgan Stanley made another unorthodox decision. ... [T] he firm had long relied on the wasp white-glove law firm of Davis, Polk, and Wardwell, which had looked on takeover work as vulgar and had avoided it. With Morgan Stanley partners terrified of lawsuits ensuing from takeover work, they now wanted a tough, seasoned specialist ... . [and hired] the experienced Joe Flom of Skadden, Arps, Slate, Meagher, \& Flom. . . . [Flom had] pioneered in hostile takeovers in the 1950s, when Skadden, Arps was still a humble, four-man operation. For twenty years, he thrived on the scraps from law firms that were too haughty or too dignified to conduct hostile raids. When Flom was made a special counsel to Morgan Stanley, there were stormy scenes with Davis, Polk partners, who were deeply offended by the decision. Whatever its other consequences, the trend in hostile takeovers democratized the New York legal world and provided an opening in Wall Street for Jewish lawyers. ${ }^{103}$

Once Morgan Stanley flipped, the old, inefficient social norm crumbled. Established corporations-including United Technologies, in 1975 104 _launched hostile takeovers bids, establishment commercial banks began financing hostile bidders, establishment law firms began representing hostile bidders, and most other investment bankers began assisting hostile bidders:

Once Morgan Stanley sanctioned hostile takeovers, competitors jumped in. A year later, George Shinn of First Boston paired up Bruce Wasserstein and Joe Perella to launch a separate M \& A operation. In 1974, $\$ 100$ million was still considered a big deal. By 1978 , over eighty deals exceeded that amount, with a $\$ 500$ - to $\$ 600$-million range already commonplace. ${ }^{105}$

In two important respects, the hostile takeover story is somewhat different than some of the stories considered up to now. In the cases of directorial care, the structure of the board, and the role of institutional shareholders, the old, inefficient norm was nonobligational, and gained its power through its licensing or insulating effect. In the takeover case, however, the old norm was obligational: Making or assisting in takeovers wasn't done-at least, not by those who conceived of themselves as bluechip players. Furthermore, while the norms in structure areas changed relatively suddenly after a tipping-point was reached, the takeover norm changed even more quickly - almost overnight-when a single key defec-

103. Chernow, supra note 102 , at 599-600.

104. See id. at 601.

105. Id. at 602 . It is sometimes thought that the hostile-takeover movement flowered when Michael Milken pioneered the use of junk bonds as a device to finance such takeovers. In fact, however, junk-bond financing was not introduced until around 1983 (when Boone Pickens used junk bonds to make a takeover bid for Gulf Oil), and the main era of junk-bond financing started around 1985. See Madrick, supra note 101, at 252-57; Edward I. Altman on Junk Bonds, as quoted im Stephen A. Ross et al., Fundamentals of Corporate Finance 376-77 (3d ed. 1993). 
tion disturbed the prevailing equilibrium. In other respects, however, the takeover story resembles those other cases by illustrating both the highly significant role of social norms in corporate law, and the way in which social norms may be bad or inefficient as well as good or efficient.

\section{Conclusion}

The role of social norms is pervasive in the law generally, and in corporate law in particular. It is not possible to fully understand corporate law without understanding both the role of social norms in that field and the effect of legal rules on those norms.

The social norms that are relevant to corporate law display various characteristics. Some, such as the old norm of directorial care, are nonobligational practices but have an effect through their power to insulate conduct from criticism. Others, such as the present norm of directorial care, are obligational and have an effect either because they are internalized or because of the prospect of reputational sanctions. Some, such as those that concern the structure of the board and hostile takeover bids, have shifted rapidly as a result of critical-mass and tipping-point phenomena. Others, such as the norm of loyalty, have been relatively stable in their general formulation but have been elaborated over time so that some conduct that once might have been viewed as tolerable, such as insider trading, is now viewed as morally impermissible.

Social norms may either increase or decrease efficiency. In the loyalty area, social norms increase efficiency by supplementing the roles of liability rules and monitoring and bonding systems. In the very recent past, however, social norms decreased efficiency in areas such as board structure, the role of institutional investors, and hostile takeovers. Indeed, one valuable lesson that can be learned from studying the role of social norms in corporate law is to reinforce the point, made in recent literature from somewhat different perspectives, ${ }^{106}$ that notwithstanding arguments based on social Darwinism, the structure of corporate institutions at any given time is not necessarily the most efficient structure.

To some extent, shifts in the social norms relevant to corporate law have been a result of changes in the external environment, such as the development of infrastructures that support institutional investor activity. In significant part, however, these norm-shifts have been the result of changes in the belief-systems of relevant corporate actors. Most obligational norms are likely to originate and stabilize only if they are internalized by a significant portion of the relevant social group. With limited exceptions, if the only reason for adhering to an obligational norm is the fear of reputational sanctions for noncompliance, and few or no members of the social group internalize the norm - that is, believe that the norms should be adhered to - the norm will probably collapse. As a

106. See articles cited in supra notes $76-79$. 
result, obligational norms depend heavily on belief systems, and shifts in obligational norms depend heavily on shifts in belief-systems.

Douglass North has observed that in economic areas of life, beliefs get translated into performance by becoming embodied in institutions. ${ }^{107}$ Corporate law illustrates this point particularly well. Changes in the belief-systems of corporate actors cause shifts in norms. These shifts, in turn, are translated into the fabric of corporate institutions and corporate law.

107. See Douglass North, Winners and Losers, Wall St. J., March 11, 1998, at A18 (reviewing David S. Landes, The Wealth and Poverty of Nations (1998)). 